\title{
A maradó fogak gyökér-korona aránya egészséges, fiatal magyar, német és japán populációkban
}

\author{
Rencz Boglárka dr. ${ }^{1}$ - Buthina Alhaddad dr. ${ }^{2}$ - Remport Boglárka dr. ${ }^{3}$ \\ Rózsa Noémi Katinka dr. ${ }^{2}$ " Mitsuo Iinuma dr. ${ }^{4}$. Tarján Ildikó dr. ${ }^{2}$ \\ ${ }^{1}$ Népszínház Dent, Budapest \\ ${ }^{2}$ Semmelweis Egyetem, Fogorvostudományi Kar, Gyermekfogászati és Fogszabályozási Klinika, Budapest \\ ${ }^{3}$ Remport-Fogászat Kft., Budapest \\ ${ }^{4}$ School of Dentistry, Asahi University, Hozumi, Japan
}

\begin{abstract}
Bevezetés: A maradó fogak gyökér-korona arányának meghatározása nagy jelentőséggel bír a fogászati kezelési terv kialakításában és későbbi módosításában.

Célkitüzés: Egészséges magyar, német és japán fiatalok maradó fogai gyökér-korona arányának meghatározása és összehasonlítása.

Módszer: Hölttä módszerét alkalmaztuk. A mérés 95 magyar, 104 japán és 110 német fiatal páciens 2001 és 2006 között készült panorámaröntgen-felvételén történt.

Eredmények: A gyökér-korona arány különbsége a nemek között nem szignifikáns, az egymásnak megfelelő antagonista fogak között sok esetben, de nem mindig, szignifikáns. A legnagyobb gyökér-korona arányt mindhárom populációban az alsó szemfogakon és az alsó második praemolaris fogakon mértük; a felső molarisok esetén a legkisebb az arány. A három nemzetet összehasonlítva szignifikáns különbséget $(p \leq 0,001)$ nem találtunk egyetlen fogtípus esetében sem. A japán és a német populáció között minden fogtípus esetén szignifikáns volt a különbség a gyökérkorona arányokban. A japán és a magyar populáció összehasonlításakor a fogtípusok felénél találtunk szignifikáns különbséget. A magyar és a német populációt összehasonlítva nagyon kevés fogtípusnál találtunk szignifikáns különbséget.

Megbeszélés: Az alsó állcsont fogainak gyökér-korona arányértékei nagyobb mértékben térnek el a populációk között, mint a felsó állcsont fogainak esetében. A gyökér-korona arány átlagértéke a német populációban a legnagyobb. A második legnagyobb arányértékkel a magyar populáció rendelkezik, utána pedig a japán, néhány fogtípus kivételével: felső kismetszők, felső szemfogak és felső első molarisok.

Következtetés: A legnagyobb gyökér-korona arány különbséget a német és a japán populáció között, a legkisebbet a magyar és a német populáció között találtuk. Cikkünk megmutatja az egyes fogtípusok gyökér-korona arányának normálértékét fiatal, egészséges magyar, német és japán populációban.
\end{abstract}

Orv Hetil. 2021; 162(46): 1848-1855.

Kulcsszavak: gyökér-korona arány, maradó fogak, összehasonlítás

\section{Root-crown ratios of permanent teeth in healthy and young Hungarian, German, and Japanese populations}

Introduction: Defining the root-crown ratio of the permanent teeth is important in making or changing proper treatment plans in dentistry.

Objective: To define and compare the root-crown ratios of the permanent teeth of healthy, young Hungarian, German, and Japanese populations.

Method: We adapted Hölttä’s method. 95 Hungarian, 104 Japanese and 110 German young patients' panoramic X-rays (made between 2001 and 2006) were involved in the investigation.

Results: Difference between the genders was found non-significant; between the corresponding antagonists many times, but not all significant. The highest root-crown ratios were found in all investigated populations by the lower canines and premolars, the lowest by the upper molars. P $\leq 0,001$ was not found among the three populations. Significant differences were found between Japanese and German populations by all tooth-types; between Japanese and Hungarian populations by near half of the tooth-types; between Hungarian and German populations by only a few tooth-types. 
Discussion: More significant differences were found in root-crown ratios in the lower jaw among the populations. The mean value of the root-crown ratios was the highest in the German population; medium in the Hungarian population; and the least in the Japanese population, with a few exceptions: upper lateral incisors, canines and first molars. Conclusion: The biggest differences were found between the German and Japanese populations; the least between the Hungarian and the German populations. Our paper describes the control values of the root-crown ratios of the tooth types in young, healthy Hungarian, German, and Japanese populations.

Keywords: root-crown ratios, permanent teeth, comparison

Rencz B, Alhaddad B, Remport B, Rózsa NK, Iinuma M, Tarján I. [Root-crown ratios of permanent teeth in healthy and young Hungarian, German, and Japanese populations]. Orv Hetil. 2021; 162(46): 1848-1855.

(Beérkezett: 2021. március 15.; elfogadva: 2021. május 4.)

\section{Rövidítések}

FDI = (Fédération Dentaire Internationale $)$ Nemzetközi Fogászati Szövetség; ICC = (interclass correlation coefficient) osztályok közötti korrelációs együttható; OTKA = Országos Tudományos Kutatási Alapprogramok

A fogászat legtöbb területén a foggyökér és a fogkorona arányának nagy a jelentősége. A fogpótlásokat úgy tervezzük, hogy a pillérfogak a rágóerőknek ellenálljanak. A fogpótláshoz elhorgonyzásra és megtámasztásra igénybe vett fogak gyökér-korona arányának ismerete elengedhetetlen. A gyermekfogászatban a gyökér-korona hányados ismeretében a fogfejlődési anomáliákat el tudjuk különíteni a normálvariációktól [1]. A fogszabályozásban a kezelési terv elkészítéséhez kell ismernünk a gyökér-korona arányokat [2-4]: a horgonylat elemzéséhez, valamint a kezelés közben alkalmazott fogszabályozási erőrendszerek tervezéséhez [1], majd a kezelés közben előforduló apicalis gyökérreszorpció meghatározása céljából értékeljük ezt a paramétert [5-7].

A gyökér-korona arány a foggyökér és a fogkorona közötti viszonyszám. Megkülönböztethetünk anatómiai és klinikai gyökér-korona arányt [8]. Az anatómiai gyökérkorona hányados kiszámításakor a zománc-cement határt tekintjük a korona és a gyökér határának. Ez apicalisabban helyezkedik el, mint a radiológiai gyökér-korona határ, valamint a fogakon nehezen látható $[9,10] . \mathrm{Az}$ előbb említettek miatt ritkán határozzuk meg az anatómiai gyökér-korona arányt. A klinikai gyökér-korona arány kiszámítása esetén az alveolus szélét vesszük viszonyítási pontnak. Ez a fognak a csontban való elhorgonyzottságáról ad információt $[8,11,12]$.

Fiatalkorban a gyökér-korona arány megváltozását két fó csoportba sorolhatjuk: 1) a fogfejlődés alatti zavar, 2) az egészségesen kifejlődött fogak gyökerének apicalis reszorpciója, ritka esetben a fogkorona abráziója. Az életkor előrehaladtával megváltozik a gyökér-korona reláció. Ennek oka lehet az attritio és a parodontalis tapadásveszteség. Az attritio a gyökér-korona arányt a gyökér javára, ezzel szemben a parodontalis tapadásveszteség a klinikai korona javára billenti el; az utóbbi következménye lehet kóros fogvándorlás és/vagy szekunder traumás okklúzió, végül az érintett fogak elvesztése is.

Léteznek szubjektív [13-15] és objektív [16] módszerek a gyökér-korona viszony meghatározására. Az irodalomban ezek használata nem következetes, ezért az eredmények nem hasonlíthatók össze [17]. A jelen tanulmányban használt módszer nem a zománc-cement határt, hanem a fogmorfológiát veszi alapul, mivel a panorámaröntgen-felvételeken az előbbi gyakran nem ismerhető fel. A használt metódus maximálisan közelíti az anatómiai gyökér-korona arány meghatározását azon információk alapján, amelyek egy panorámaröntgen-felvételből kinyerhetők. Lind 1972-ben írta le ezt a módszert intraoralis röntgenfelvételek értékelésének céljából [18], majd Hölttä adaptálta 2004-ben panorámaröntgen-felvételekre [16]. Hátránya, hogy nem ad kellő információt a fogak csontban való elhorgonyzottságáról és a parodontium állapotáról.

A rutin-panorámaröntgenekkel való kutatómunka előnyös sugárvédelmi és logisztikai szempontból, ennek ellenére nem mindenki preferálja. A fent említett finn kutatócsoport meghatározta a fiatal, egészséges finn populáció gyökér-korona arányának normálértékeit [16]. A jelen tanulmány célja ugyanezzel a módszerrel meghatározni és összehasonlítani egészséges magyar, német és japán fiatalok gyökér-korona arányait, és ezzel kapcsolatban leírást készíteni a populációk fó jellegzetességeiről, a különbségekról és a közös jegyekről.

\section{Anyag és módszer}

95 magyar, 104 japán és 110 német, fiatal, egészséges páciens panorámaröntgen-felvételét vizsgáltuk. Vizsgálatunkban a férfiak átlagéletkora: $15,3 / 18,6 / 15,4( \pm 2,7 /$ $2,1 / 2,5)$ év, a nőké: $14,6 / 19 / 15,6( \pm 2,8 / 2,2 / 2,6)$ év magyar/japán/német sorrendben. A vizsgálatban részt vevő személyek (panorámaröntgenek) száma: 40/45/51 fö magyar/japán/német férfi és $55 / 59 / 51$ fö magyar/ japán/német női páciens.

A magyar minta a budapesti Semmelweis Egyetem Gyermekfogászati és Fogszabályozási Klinikáján megjelent páciensek adatait tartalmazza. A japán minta a 


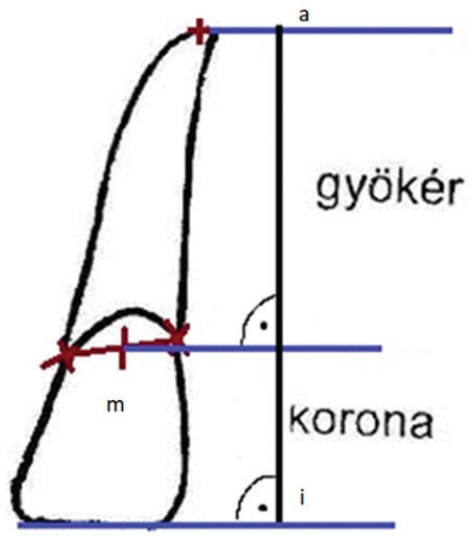

1. ábra

| A mérési pontok meghatározása

Hozumi Asahi Egyetem Gyermekfogászati Klinikája pácienseinek mintáit, a német minta a freiburgi (Freiburg im Breisgau) Albert Ludwig Egyetem pácienseinek mintáit tartalmazza. Rutin-panorámaröntgeneket használtunk. A felvételeket 2001 és 2006 között készítették. A Lind, majd 2004-ben Hölttö által leírt, panorámaröntgen-felvételekre adaptált módszert alkalmaztuk [16, 18]. A mérések elvégzését populációnként egy kutató végezte méréskalibráció után 2005 és 2008 között. A mérési pontok meghatározását az 1 . ábra mutatja, a röntgenkiértékelést pedig a 2. ábra szemlélteti.

A buccolingualisan túlzottan inklinált fogakat kevésbé pontosan lehet mérni, ezért ezeket a fogakat kizártuk méréseinkből (Hölttä és mtsai [16]). A palatinalis gyökerek, főleg, ha a korona síkjától divergálnak, gyakran nagyítva képeződnek le a panorámaröntgeneken, ezért ezeket is kizártuk méréseinkból [19].

Mivel korábbi vizsgálatban [16] nem találtak szignifikáns különbséget a jobb és a bal oldali identikus fogak között (tehát például a jobb és a bal felső első nagymetsző gyökér-korona aránya nem különbözik egymástól szignifikánsan), a jobb és bal oldali identikus fogakat
1. táblázat $\mid \begin{aligned} & \text { A fogak Fédération Dentaire Internationale (FDI) szerinti jelö- } \\ & \text { lése }\end{aligned}$ lése

\begin{tabular}{ccccccc|cccccccc}
\hline \multicolumn{4}{c|}{ Jobb felső kvadráns } & \multicolumn{6}{c}{ Bal felső kvadráns } \\
\hline 17 & 16 & 15 & 14 & 13 & 12 & 11 & 21 & 22 & 23 & 24 & 25 & 26 & 27 \\
\hline 47 & 46 & 45 & 44 & 43 & 42 & 41 & 31 & 32 & 33 & 34 & 35 & 36 & 37 \\
\hline \multicolumn{4}{c|}{ Jobb alsó kvadráns } & \multicolumn{4}{c}{ Bal alsó kvadráns } \\
\hline
\end{tabular}

fogcsoportoknak nevezzük, adataikat egy halmazban kezeljük. Ezáltal az egy panorámaröntgenen vizsgált 28 fogat 14 fogcsoportra osztottuk. A fogak FDI-jelölését mutatja be az 1. táblázat.

A vizsgálatot végző három kutató megbízhatósági vizsgálat céljából lemérte ugyanazt a 140 fogat (tíz panorámaröntgen-felvételt), majd az eredményeket statisztikailag elemeztük. Szignifikáns különbséget nem találtunk az egyes mérések között a kalibráció során.

$\mathrm{Az}$ alsó második praemolaris fogak esetén volt a legalacsonyabb a Kendall-féle konkordancia együtthatója (W): 0,6148, a legalacsonyabb ,interclass correlation coefficient" (ICC) pedig 0,73 volt. A legnagyobb W-értéket 1-nek találtuk, mégpedig a felső és alsó második molarisok esetében. A legnagyobb ICC 0,96 volt az alsó második molarisoknál és 0,95 a felső második molarisoknál. Mindezekből levontuk azt a következtetést, hogy a mérést végző három kutató munkája egymáshoz képest hitelesített.

A magyar/japán/német populációban 2389/2828/ 2779 fogat vizsgáltunk meg a leképezett 2660/2912/ 3080 fogból $(89,8 \% / 97,1 \% / 90,2 \%)$.

A statisztikai analízisre az R 3.0.1 (R Foundation for Statistical Computing, Bécs, Ausztria) statisztikai programot használtuk, az ismételt mérések statisztikai elemzésére (kalibráció), kivéve a Friedman-teszthez, amelyet GraphPad Instat 3 (Graphpad Software, La Jolla, CA, USA) programmal végeztünk. Statistica 8.0 (StatSoft

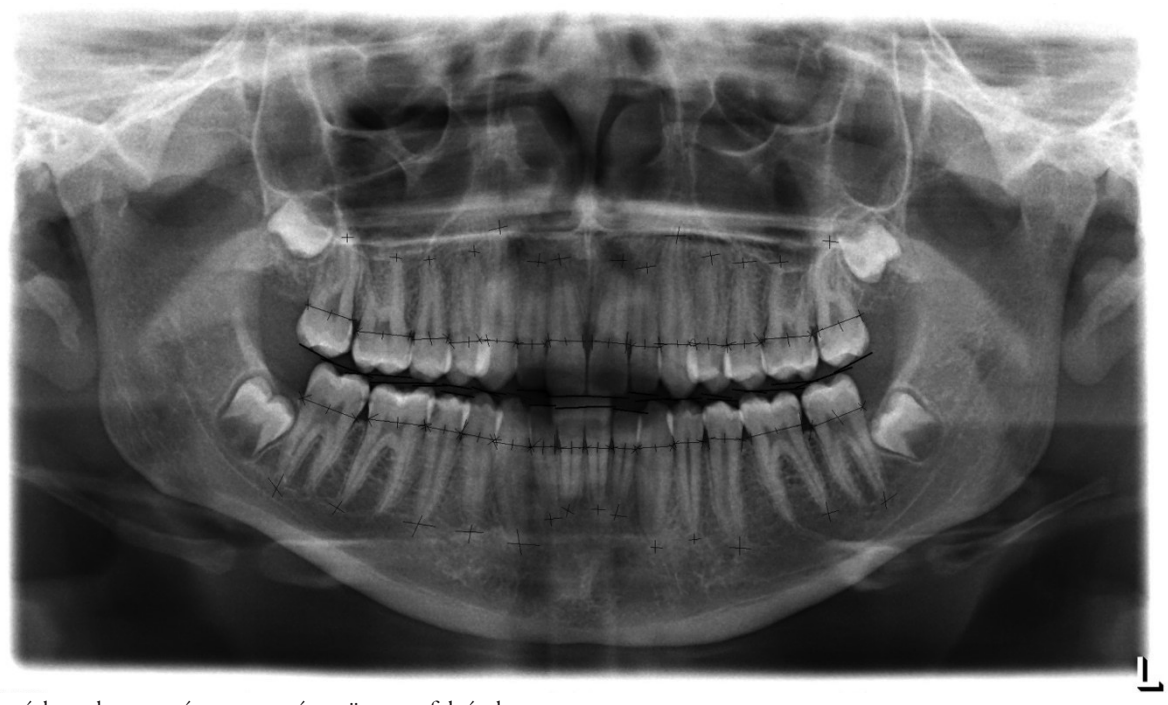


Inc., Tulsa, OK, USA) programot használtunk az összehasonlító vizsgálatokhoz (nem az ismételt vizsgálatokhoz). Az eredményeket akkor tekintettük szignifikánsnak, ha a p-érték 0,05 vagy kevesebb volt. A szisztémás hiba vizsgálatát a Friedman-teszt Dunn post hoc tesztjével végeztük (a p-érték 0,0966 volt). Az 'intra- és interobserver' varianciavizsgálatokhoz Levene-próbát használtunk. A véletlen hiba vizsgálatát három statisztikai módszerrel végeztük: 1) Bland-Altman plot (vagy Tukey-próba); 2) 'MethComp' csomag; 3) Dahlberg d (Dd)-vizsgálat.

\section{Eredmények}

A Kruskal-Wallis-teszt („multiple comparisons of mean ranks" post hoc, amit a továbbiakban $\mathrm{z}$ post hoc-nak hívunk) p-értéke mind a 14 fogtípusnál <0,0001. Azaz mindegyik fogtípus szignifikánsan különbözik egymás-

2. táblázat |A japán férfi- és női populáció gyökér-korona arányai

\begin{tabular}{|c|c|c|c|c|}
\hline $\begin{array}{l}\text { Japán populáció } \\
\text { Fogtípus }\end{array}$ & Mintaszám & Átlag & Medián & $\begin{array}{l}\text { Standard } \\
\text { deviáció }\end{array}$ \\
\hline 11 (férfi ) & 42 & 1,6685 & 1,6600 & 0,3297 \\
\hline 12 (férfi) & 43 & 1,7813 & 1,8000 & 0,3526 \\
\hline 13 (férfi) & 45 & 1,8324 & 1,8300 & 0,3241 \\
\hline 14 (férfi) & 45 & 1,7104 & 1,7000 & 0,2982 \\
\hline 15 (férfi) & 44 & 1,8229 & 1,8250 & 0,3233 \\
\hline 16 (férfi) & 45 & 1,5406 & 1,5000 & 0,3136 \\
\hline 17 (férfi) & 45 & 1,5608 & 1,5000 & 0,3473 \\
\hline 41 (férfi) & 43 & 1,6553 & 1,6600 & 0,3105 \\
\hline 42 (férfi) & 43 & 1,7237 & 1,8000 & 0,3493 \\
\hline 43 (férfi) & 43 & 1,7681 & 1,8100 & 0,2895 \\
\hline 44 (férfi) & 45 & 1,6793 & 1,6300 & 0,2513 \\
\hline 45 (férfi) & 44 & 1,8125 & 1,8050 & 0,2514 \\
\hline 46 (férfi) & 44 & 1,5963 & 1,5250 & 0,2754 \\
\hline 47 (férfi) & 45 & 1,5144 & 1,4400 & 0,2767 \\
\hline 11 (nô) & 46 & 1,5076 & 1,5150 & 0,2130 \\
\hline 12 (nô) & 46 & 1,6815 & 1,6600 & 0,2561 \\
\hline 13 (nó) & 46 & 1,9076 & 1,8900 & 0,3569 \\
\hline 14 (nô) & 45 & 1,6791 & 1,6300 & 0,3050 \\
\hline 15 (nô) & 45 & 1,7275 & 1,7700 & 0,3282 \\
\hline 16 (nő) & 44 & 1,5734 & 1,5500 & 0,3014 \\
\hline 17 (nô) & 46 & 1,4876 & 1,4750 & 0,2247 \\
\hline 41 (nô) & 46 & 1,5439 & 1,5400 & 0,2495 \\
\hline 42 (nő) & 45 & 1,6846 & 1,6600 & 0,2100 \\
\hline 43 (nô) & 44 & 1,8859 & 1,9000 & 0,3153 \\
\hline 44 (nô) & 44 & 1,8147 & 1,7600 & 0,3270 \\
\hline 45 (nô) & 45 & 1,8608 & 1,8000 & 0,3637 \\
\hline 46 (nó) & 46 & 1,5743 & 1,4750 & 0,3376 \\
\hline 47 (nô) & 45 & 1,5468 & 1,5000 & 0,3038 \\
\hline
\end{tabular}

tól, tehát külön kell vizsgálnunk őket. Az egész mintát analizálva azt találtuk, hogy a korreláció az egyes fogtípusok között: R (Spearman-féle korrelációs koefficiens) 0,19 és 0,74 között van, ami nem mutat szoros korrelációt. Az egymásnak megfelelő antagonista fogak esetén szintén nem kaptunk szoros korrelációt.

A statisztikai vizsgálatokkal kimutattuk, hogy a három vizsgáló személy kalibrálása sikeres volt, és hogy a minta alkalmas klinikai kiértékelésre. Nem találtunk szignifikáns eltérést a nemek között fogtípusok szerint vizsgálva (z post hoc). A mandibularis fogak gyökér-korona aránya minden esetben nagyobb volt. Vizsgálatunkban a japán férfipopulációban nem találtunk szignifikáns különbséget (z post hoc) az egymásnak megfelelő antagonista fogak esetében. Minden más populációnál szignifikáns volt a különbség.

A csoportok közötti különbségeket Kruskal-Wallisteszttel vetettük statisztikai analízis alá. Hat csoportot

3. táblázat |A magyar férfi- és női populáció gyökér-korona arányai

\begin{tabular}{|c|c|c|c|c|}
\hline $\begin{array}{l}\text { Magyar populáció } \\
\text { Fogtípus }\end{array}$ & Mintaszám & Átlag & Medián & $\begin{array}{l}\text { Standard } \\
\text { deviáció }\end{array}$ \\
\hline 11 (férfi) & 36 & 1,8413 & 1,8300 & 0,3490 \\
\hline 12 (férfi) & 35 & 2,1582 & 2,1900 & 0,4122 \\
\hline 13 (férfi) & 39 & 2,1838 & 2,1300 & 0,3922 \\
\hline 14 (férfi) & 35 & 1,8851 & 1,8300 & 0,3164 \\
\hline 15 (férfi) & 36 & 2,0052 & 2,0000 & 0,3623 \\
\hline 16 (férfi) & 38 & 1,5376 & 1,5100 & 0,2855 \\
\hline 17 (férfi) & 31 & 1,6680 & 1,7000 & 0,3487 \\
\hline 41 (férfi) & 35 & 1,9074 & 1,8500 & 0,3250 \\
\hline 42 (férfi) & 37 & 2,0835 & 2,0000 & 0,3793 \\
\hline 43 (férfi) & 38 & 2,3521 & 2,3200 & 0,4413 \\
\hline 44 (férfi) & 38 & 2,2042 & 2,2000 & 0,4054 \\
\hline 45 (férfi) & 33 & 2,4193 & 2,3600 & 0,3478 \\
\hline 46 (férfi) & 36 & 2,0850 & 2,0450 & 0,2942 \\
\hline 47 (férfi) & 28 & 1,8085 & 1,7700 & 0,2713 \\
\hline 11 (nő) & 54 & 1,8735 & 1,8350 & 0,3357 \\
\hline 12 (nő) & 49 & 2,1812 & 2,1600 & 0,3194 \\
\hline 13 (nő) & 53 & 2,1622 & 2,2200 & 0,3261 \\
\hline 14 (nő) & 50 & 1,8992 & 1,8750 & 0,2802 \\
\hline 15 (nő) & 53 & 1,9313 & 1,9500 & 0,2698 \\
\hline 16 (nő) & 52 & 1,5511 & 1,5100 & 0,2672 \\
\hline 17 (nő) & 46 & 1,5693 & 1,5700 & 0,2959 \\
\hline 41 (nő) & 52 & 2,1284 & 2,0650 & 0,3311 \\
\hline 42 (nő) & 53 & 2,1169 & 2,1000 & 0,3040 \\
\hline 43 (nő) & 52 & 2,3517 & 2,3300 & 0,3593 \\
\hline 44 (nő) & 55 & 2,2640 & 2,2700 & 0,3880 \\
\hline 45 (nő) & 47 & 2,4344 & 2,3800 & 0,3844 \\
\hline 46 (nő) & 52 & 2,0946 & 2,0800 & 0,3380 \\
\hline 47 (nő) & 37 & 1,9664 & 2,0000 & 0,3090 \\
\hline
\end{tabular}


képeztünk a három nemzetből és a két nemből. A gyökér-korona arányok átlagértékei csökkenő sorrendben a három populációban: német, magyar, japán, az alábbi fogak kivételével: felső első molarisok, felső szemfogak és felső kismetszők (2., 3. és 4. táblázat). A legnagyobb és legkisebb gyökér-korona arányú fogakat populációkra lebontva az 5. táblázat mutatja.

4. táblázat | A német férfi- és női populáció gyökér-korona arányai

\begin{tabular}{lcccc}
\hline $\begin{array}{l}\text { Német populáció } \\
\text { Fogtípus }\end{array}$ & Mintaszám & Átlag & Medián & $\begin{array}{c}\text { Standard } \\
\text { deviáció }\end{array}$ \\
\hline 11 (férfi) & 44 & 2,1765 & 2,1400 & 0,3286 \\
12 (férfi) & 48 & 2,4235 & 2,3800 & 0,4713 \\
13 (férfi) & 47 & 2,2582 & 2,2500 & 0,4165 \\
14 (férfi) & 46 & 2,1473 & 2,0650 & 0,3872 \\
15 (férfi) & 42 & 2,1319 & 2,1650 & 0,4336 \\
16 (férfi) & 43 & 1,9025 & 1,8800 & 0,3147 \\
17 (férfi) & 34 & 1,9282 & 1,9100 & 0,3267 \\
41 (férfi) & 47 & 2,1978 & 2,1700 & 0,3509 \\
42 (férfi) & 48 & 2,2391 & 2,2150 & 0,2853 \\
43 (férfi) & 48 & 2,3072 & 2,3900 & 0,3566 \\
44 (férfi) & 48 & 2,4012 & 2,4150 & 0,3741 \\
45 (férfi) & 39 & 2,5310 & 2,5000 & 0,4012 \\
46 (férfi) & 45 & 2,2071 & 2,2100 & 0,2608 \\
47 (férfi) & 26 & 2,2488 & 2,1950 & 0,2517 \\
11 (nó) & 43 & 2,0630 & 2,1000 & 0,3786 \\
12 (nó) & 41 & 2,1380 & 2,1100 & 0,3024 \\
13 (nó) & 45 & 2,2013 & 2,1600 & 0,4623 \\
14 (nó) & 43 & 2,0083 & 2,0000 & 0,3703 \\
15 (nő) & 42 & 2,1523 & 2,1350 & 0,4075 \\
16 (nő) & 43 & 1,8662 & 1,8300 & 0,4453 \\
17 (nő) & 33 & 1,9678 & 1,8800 & 0,4595 \\
41 (nó) & 44 & 2,1950 & 2,1100 & 0,3488 \\
42 (nó) & 45 & 2,2282 & 2,2300 & 0,3877 \\
43 (nó) & 45 & 2,3575 & 2,4000 & 0,4854 \\
44 (nó) & 46 & 2,3802 & 2,4050 & 0,3371 \\
45 (nó) & 40 & 2,4995 & 2,4850 & 0,3306 \\
46 (nó) & 40 & 2,2187 & 2,1650 & 0,2685 \\
47 (nó) & 34 & 2,1382 & 2,1150 & 0,2814 \\
\hline
\end{tabular}

5. táblázat |A legkisebb és a legnagyobb gyökér-korona arányú fogak populációnként és foganként

\begin{tabular}{lcc}
\hline & $\begin{array}{c}\text { Kis R/C értékû } \\
\text { fogtípusok }\end{array}$ & $\begin{array}{c}\text { Nagy R/C értékű } \\
\text { fogtípusok }\end{array}$ \\
\hline Magyar populáció & $16,17,11,14$ & $45,43,44$ \\
Német populáció & $16,17,11,14$ & $45,43,44$ \\
Japán populáció & $16,17,46,47,11$, & $45,43,15,13$ \\
& 14,41 & \\
\hline
\end{tabular}

$\mathrm{C}=$ korona (crown); $\mathrm{R}=$ gyökér $($ radix $)$
6. táblázat |A populációk gyökér-korona arányának összehasonlítása fogtípusok és szignifikanciaszint szerint

\begin{tabular}{|c|c|c|c|}
\hline & $\begin{array}{c}\text { Fogtípusok nem } \\
\text { szignifikáns } \\
\text { viszonyban }\end{array}$ & $\begin{array}{c}\text { Fogtípusok } \\
\mathrm{p} \leq 0,05-0,001 \\
\text { viszonyban }\end{array}$ & $\begin{array}{l}\text { Fogtípusok } \\
\mathrm{p} \leq 0,001 \\
\text { viszonyban }\end{array}$ \\
\hline Magyar-német & $\begin{array}{c}12,42,13,43 \\
14,44,15,45 \\
46\end{array}$ & $\begin{array}{c}11,41,16,17 \\
47\end{array}$ & $11,16,17,47$ \\
\hline Magyar-japán & $\begin{array}{c}14,15,16,17 \\
41\end{array}$ & $\begin{array}{c}42,43,44,45 \\
46,47,11,12 \\
13\end{array}$ & $\begin{array}{c}12,42,43,44 \\
45,46\end{array}$ \\
\hline Német-japán & - & $\begin{array}{l}11,12,13,14 \\
15,16,17,41 \\
42,43,44,45 \\
46,47\end{array}$ & $\begin{array}{c}12,42,43,44 \\
45,46,47\end{array}$ \\
\hline
\end{tabular}

A három populáció egymásnak megfelelő fogtípusait összehasonlítva, $\mathrm{p} \leq 0,001$ értéket egyik fogtípusnál sem találtunk. A japán és a német populáció között minden fogtípus esetében szignifikáns különbséget találtunk. A japán és a magyar populációt összehasonlítva, a fogtípusok majdnem felénél találtunk szignifikáns különbséget. A magyar és a német populációt összehasonlítva, nagyon kis különbséget találtunk az adott fogtípusok között (6. táblázat).

A populációk összehasonlításakor több szignifikáns különbséget találtunk az alsó állcsont gyökér-korona viszonyszámaiban, mint a felsőében (6. táblázat).

A 3. ábra grafikusan szemlélteti a gyökér-korona arányok átlagainak populációk közötti viszonyát.

\section{Megbeszélés}

1972-ben Lind [18] definiált egy módszert a felső centrális metszők gyökér-korona arányának meghatározására. 2004-ben Hölttä és mtsai [16] leírtak egy eljárást az összes fogtípus gyökér-korona viszonyszámának meghatározására panorámaröntgen-felvételek alapján, Lind metódusát adaptálva ortopantomogramokra. Tanulmányunkban Hölttä és munkatársai módszerét alkalmaztuk. A gyökér-korona arány meghatározása előnyösebb a korona és a gyökér abszolút hosszértékeinek figyelembevétele helyett, mivel az előbbit a röntgen torzító hatása kevésbé befolyásolja [20,21]. A gyökér-korona arány meghatározása fontos, hiszen a fog rágóereje, stabilitása és funkcionalitása ennek a hányadosnak is a függvénye. A panorámaröntgenek reprodukálhatók és vertikálisan megbízhatók [19, 22, 23]. Nagyításuk a különböző röntgengépek használata miatt vagy az egy röntgenen belüli különböző régiókban más-más lehet $[19,21]$, de jelentősen nem befolyásolja a gyökér-korona arányt, mert a fog gyökere és koronája szinte ugyanazon a vertikális síkon helyezkedik el, továbbá populációnként ugyanazt a röntgenkészüléket használtuk.

Homályos és torzult kép alakulhat ki a fejnek az exponálás közbeni elmozdulása miatt. A fogak buccolingualis 


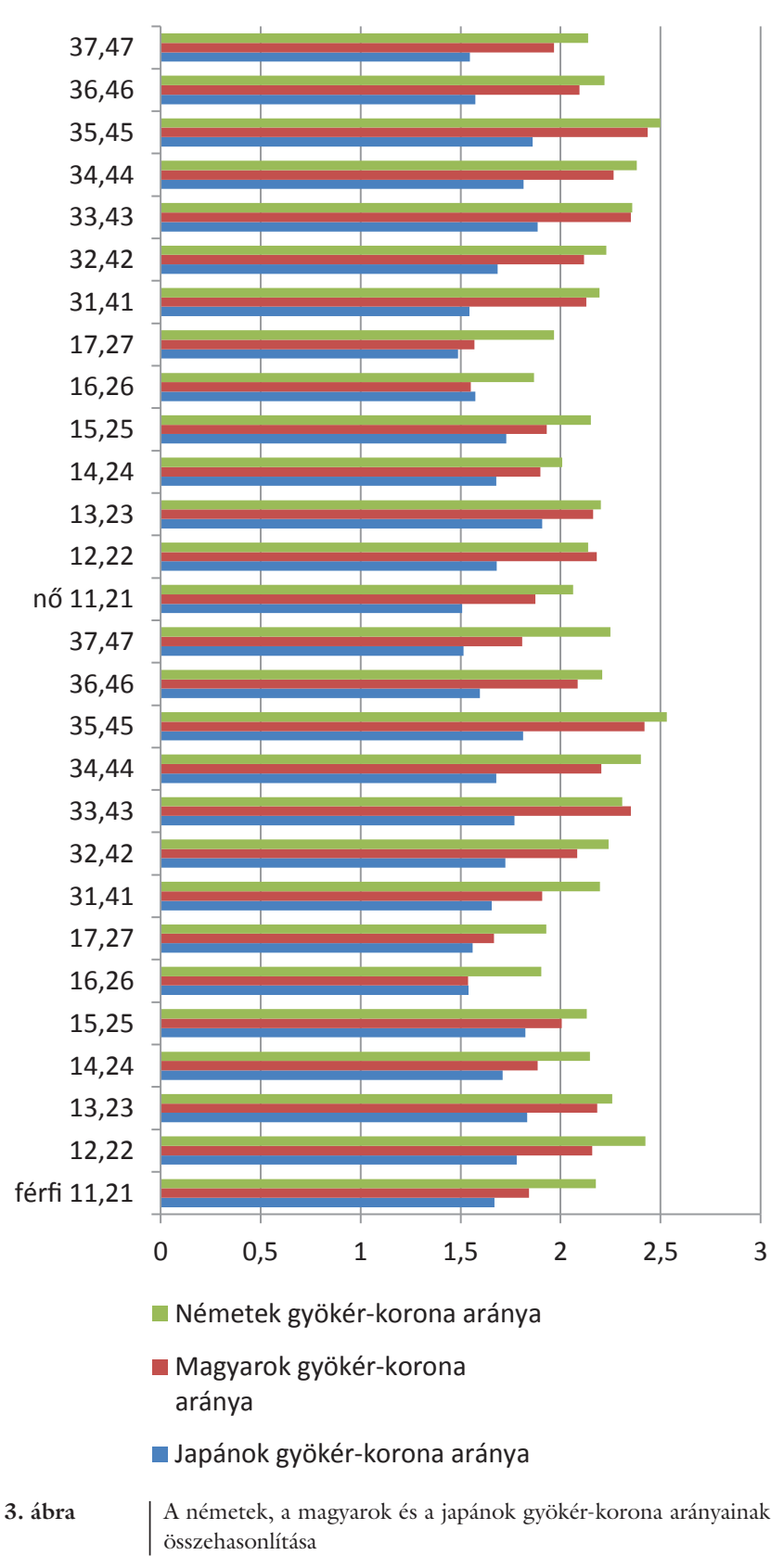

túlzott inklinációja mérési pontatlanságot okozhat, angulatiós eltérése megváltoztatja a fog radiológiai hosszúságát, de a gyökér és a korona arányát nem módosítja. [24]. A panorámaröntgen-felvételek készítése közben a fej pozicionálási hibái a leggyakoribbak, az értékelési hibák között pedig a referenciapontok meghatározásában lehetnek tévedések [23]. Ezek a hibák szignifikánsan megváltoztathatják a kapott arányértéket [17].

A fentebb említett pontatlanságok kiküszöbölése céljából megbizonyosodtunk arról, hogy a röntgenfelvételeket egy-egy adott röntgenközpontban készítették minden vizsgált populáció esetében. A röntgenek megfelelő minőségét a fej standardizált beállításával értük el. A felvételeket három, radiológiában jártas szakember készítette. Csak a megfelelő minőségú röntgeneket vontuk be a tanulmányba. A zománc-cement határvonal a röntgen- felvételeken nem látszik, ezért fogmorfológiai referenciapontokat használtunk. A mérési hiba csökkentése céljából populációnként egy vizsgáló mérte a gyökér-korona arányokat.

Méréseinkben az alsó állcsont fogainak mindig nagyobb volt a gyökér-korona aránya, mint a felső állcsont identikus fogainak. Minden vizsgálati csoportunkban az antagonista fogtípusok gyökér-korona hányadosa szignifikánsan különbözött, kivéve a japán férficsoportot. A gyökér-korona viszony átlagértéke a német populációban volt a legnagyobb. A legkisebb gyökér-korona értékeket mindhárom, általunk vizsgált populációban a felső molarisok esetében találtuk. A japánok alsó molarisainak gyökér-korona arányai a legkisebbek az általunk vizsgált populációkban, aminek oka valószínúleg ezen csoport mandibuláinak a magyarokéhoz és a németekéhez képest eltérő anatómiai adottságaiban keresendő.

A Bolk-féle terminális redukciós elmélet különböző megnyilvánulásaiként értelmezhetjük az alábbi eredményeinket: az alsó centrális metszők esetében a vizsgálatok a japán populációban kis arányértékeket találtak, a másik két populációban közepeseket, tehát valószínúleg rövidebb gyökérrel rendelkeznek. A felső kismetszők gyökér-korona hányadosa a japán és német nőcsoportban közepes volt. A japán, német és magyar férficsoportban nagy arányszámot kaptunk, tehát ezen fogak koronája sok vizsgált alany esetében valószínúleg kicsi. A korábban hivatkozott finn cikkben [16] az alsó centrális metszők értékei is kicsik, a felső kismetszők értékei pedig közepesek.

Hölttä 2004. évi finn vizsgálatait [16] a jelen kutatási adatokkal összehasonlítva a következő megállapításokat tehetjük: a finn populáció esetében mért gyökér-korona hányadosok átlagértékei nagyobbak voltak a magyar értékeknél, és kisebbek a német értékeknél, három fogtípus kivételével: a felső kismetszők, valamint az alsó és felső szemfogak. Az utóbbi kivételeknél a gyökér-korona arány nagyobb volt a magyar populációban. A finn populációban a németekénél nagyobb gyökér-korona viszony volt megfigyelhető négy fogtípus esetében: felső praemolarisok, felső második molarisok, alsó első praemolarisok; a megállapítások férfiak és nők esetén is igazak voltak. A finnek felső középső metszőinek arányértékei még az általunk mért értékeknél is kisebbek. A japánok és finnek alsó molarisainak gyökér-korona arányai a legkisebbek, az általunk vizsgált japánokéhoz hasonlóan, aminek oka valószínúleg ezen csoportok mandibuláinak a magyarokéhoz és németekéhez képest eltérő anatómiai adottságaiban keresendő.

Lind és Jakobsson és Lind [18, 25] eredményeivel összhangban lévő, de a Hölttä cikkében [16] publikáltakkal ellentétes eredményt kaptunk a mi vizsgálatainkban, hiszen a gyökér-korona arányt nem találtuk szignifikánsnak a nemek között egyik populációban sem. Nem találtunk szignifikáns különbséget egyetlen fogtípusnál sem a három nemzetet összehasonlítva, amely tény igazolni látszik, hogy ezzel a paraméterrel nem lehet meghatározni 
a vizsgált egyének nemzetiségét. A három ország lakosainak alsó fogai között több szignifikáns különbség található, mint a felső fogak között, ami valószínúleg az eltérő anatómiai viszonyokból eredeztethető. A német és japán populáció minden mandibulában található fogtípusánál szignifikánsan eltértek a gyökér-korona arányok, a japán és magyar populáció pedig majdnem minden alsó fogtípusánál (kivétel: az alsó centrális metszők). A tény, hogy a japán populáció alsó fogai ilyen mértékben különböznek a magyar és a német populáció alsó fogaitól, azt jelzi, hogy közöttük jelentős népességkeveredés nem történt a történelemben. A magyar és a német populáció között ellenben csak 4 fogtípus gyökér-korona hányadosai esetében találtunk szignifikáns különbséget: a felső centrális metszők, a felső molarisok és az alsó második molaris esetén, ami érdekes indikátora e két populáció közötti népességkeveredésnek a történelem során.

\section{Következtetés}

A német és a japán populáció gyökér-korona arányszámaiban találtuk a legnagyobb különbséget. A legkisebb különbség a magyar és a német populáció között volt. A japán férfipopulációban nem találtunk szignifikáns különbséget az egymásnak megfelelő antagonista fogak esetében; a többi vizsgálati csoportban a különbség szignifikáns volt, tehát az alsó és a felső fogak gyökér-korona viszonyszámai méréseink nagy részében szignifikánsan különböznek. A nemek között a gyökér-korona arány szempontjából méréseink szerint nincs különbség.

A jelen tanulmány feltárja az egészséges magyar, német és japán fiatalok gyökér-korona arányainak normálértékeit. Ezek az eredmények hasznos információként szolgálhatnak a klinikumban dolgozó orvosoknak, valamint összehasonlításképpen más csoportok, nemzetek számára, akár antropológiai célú kutatásokhoz is. A módszer klinikai vizsgálatokban is alkalmazható. Megállapíthatjuk, hogy orthodontiai kezelések és traumás sérülések után változik-e a gyökér-korona arány. Adatot kaphatunk arra is, hogy milyen fogszabályozási rendellenességek, illetve traumás sérülések kezelése után mutatkozik a legnagyobb gyökér-korona arány változás. Népegészségügyi szempontból kiemelendő, hogy a kis gyökér-korona arányú, tehát rövid gyökerü fogakkal rendelkező páciensek fokozottabb figyelmet igényelnek. Olyan népcsoportok esetében, amelyeknél a fogak anatómiai gyökér-korona aránya népességszinten kisebb, de a parodontium állapota nem különbözik más népcsoportokétól, a parodontológiai gondozást fokozottabban meg kell szervezni, és még nagyobb a szájhigiénés edukáció fontossága. Olyan nemzetek esetén, amelyeknél a gyökér-korona átlagos aránya kicsi, a fogszabályozó szakorvosokat különös figyelemmel szükséges ösztönözni a kezelések speciális biomechanikai szempontjainak megvalósítására: például a statikailag determinált biomechanikai rendszerek alkalmazására, különösen a felnőtt fogszabályozásos esetekben.
Anyagi támogatás: A kutatómunkához az anyagi támogatást az OTKA $75782 \mathrm{~K}$ pályázata biztosította.

Szerzôi munkamegosztás: R. B.: Magyarországi adatgyüjtés; a gyökér-korona arányok kiszámítása Magyarország vonatkozásában. B. A.: Irodalomkutatás, a közlemény megírása. R. B: A németországi adatok begyújtése és a gyökér-korona arányok kiszámítása; az eredetileg angolul megírt cikkének magyarra fordítása. R. N. K.: A kutatómunka és a közlemény megírásának irányítása, a cikk végleges tartalmának és formájának ellenőrzése. M. I.: A japán adatok szolgáltatása. T. I.: A cikk elkészítésében részt vevő szerzők támogatása és munkájuk összehangolása. A cikk végleges változatát valamennyi szerző elolvasta és jóváhagyta.

Érdekeltségek: A szerzőknek nincsenek érdekeltségeik.

\section{Köszönetnyilvánítás}

Nagyon köszönjük $d r$. Dirk Schulze-nak és a freiburgi egyetem munkatársainak a segítséget, az együttmúködést, a panorámaröntgenek megosztását a kísérletben.

Végtelen hálával tartozunk továbbá $d r$. Fábián Gábornak, a Gyermekfogászati és Fogszabályozási Klinika 2016-ban elhunyt egykori igazgatójának a munkában nyújtott nagylelkû segítségéért, irányításáért és támogatásáért.

\section{Irodalom}

[1] Bjorndal AM, Henderson WG, Skidmore AE, et al. Anatomic measurements of human teeth extracted from males between the ages of 17 and 21 years. Oral Surg Oral Med Oral Pathol. 1974; 38: 791-803.

[2] Wang J, Rousso C, Christensen BI, et al. Ethnic differences in the root to crown ratios of the permanent dentition. Orthod Craniofac Res. 2019; 22: 99-104.

[3] Haghanifar S, Moudi E, Abbasi S, et al. Root-crown ratio in permanent dentition using panoramic radiography in a selected Iranian population. J Dent (Shiraz). 2014; 15: 173-179.

[4] Grossmann Y, Sadan A. The prosthodontic concept of crown-toroot ratio: a review of the literature. J Prosthet Dent. 2005; 93: $559-562$.

[5] Gay G, Ravera S, Castroflorio T, et al. Root resorption during orthodontic treatment with Invisalign ${ }^{\circledR}$ : a radiometric study. Prog Orthod. 2017; 18: 12.

[6] Puranik CP, Hill A, Henderson Jeffries K, et al. Characterization of short root anomaly in a Mexican cohort - hereditary idiopathic root malformation. Orthod Craniofac Res. 2015; 18(Suppl 1): 62-70.

[7] Sondeijker CF, Lamberts AA, Beckmann SH, et al. Development of a clinical practice guideline for orthodontically induced external apical root resorption. Eur J Orthod. 2020; 42: 115-124.

[8] Yun HJ, Jeong JS, Pang NS, et al. Radiographic assessment of clinical root-crown ratios of permanent teeth in a healthy Korean population. J Adv Prosthodont. 2014; 6: 171-176.

[9] Mavragani M, Vergari A, Selliseth NJ, et al. A radiographic comparison of apical root resorption after orthodontic treatment with a standard edgewise and a straight-wire edgewise technique. Eur J Orthod. 2000; 22: 665-674.

[10] Sameshima GT, Asgarifar KO. Assessment of root resorption and root shape: periapical vs panoramic films. Angle Orthod. 2001; 71: 185-189. 
[11] Midtbø M, Halse A. Root length, crown height, and root morphology in Turner syndrome. Acta Odontol Scand. 1994; 52: 303-314.

[12] Schalk-van der Weide Y, Steen WH, Bosman F. Taurodontism and length of teeth in patients with oligodontia. J Oral Rehabil. 1993; 20: 401-412

[13] Dahllöf G, Barr M, Bolme P, et al. Disturbances in dental development after total body irradiation in bone marrow transplant recipients. Oral Surg Oral Med Oral Pathol. 1988; 65: 41-44.

[14] Näsman M, Forsberg CM, Dahllöf G. Long-term dental development in children after treatment for malignant disease. Eur J Orthod. 1997; 19: 151-159.

[15] Sonis A, Tarbell N, Valachovic R, et al. Dentofacial development in long-term survivors of acute lymphoblastic leukemia. A comparison of three treatment modalities. Cancer 1990; 66: 26452652.

[16] Hölttä P, Nyström M, Evälahti $M$, et al. Root-crown ratios of permanent teeth in a healthy Finnish population assessed from panoramic radiographs. Eur J Orthod. 2004; 26: 491-497.

[17] Stramotas S, Geenty JP, Darendeliler MA, et al. The reliability of crown-root ratio, linear and angular measurements on panoramic radiographs. Clin Orthod Res. 2000; 3: 182-191.

[18] Lind V. Short root anomaly. Scand J Dent Res. 1972; 80: 85-93.

[19] Thanyakarn C, Hansen K, Rohlin M, et al. Measurements of tooth length in panoramic radiographs. 1 : The use of indicators. Dentomaxillofac Radiol. 1992; 21: 26-30.
[20] Larheim T, Svanaes DB. Reproducibility of rotational panoramic radiography: mandibular linear dimensions and angles. Am J Orthod Dentofacial Orthop. 1986; 90: 45-51.

[21] Welander U, Tronje G, McDavid WD. Theory of rotational panoramic radiography. In: Langland OE, Langlais RP, McDavid W, et al. (eds.) Panoramic radiology. 2nd edn. Lea and Febiger Press, Philadelphia, PA, 1989; pp. 38-75.

[22] Carels CE, Kuijpers-Jagtman AM, van der Linden FP, et al. Age reference charts of tooth length in Dutch children. J Biol Buccale 1991; 19: 297-303.

[23] Larheim T, Svanaes DB, Johannessen S. Reproducibility of radiographs with the orthopantomograph 5: tooth-length assessment. Oral Surg Oral Med Oral Pathol. 1984; 58: 736-741.

[24] Brook AH, Holt RD. The relationship of crown length to root length in permanent maxillary central incisors. Proc Br Paedod Soc. 1978; 8: 17-20.

[25] Jakobsson R, Lind V. Variation in root length of the permanent maxillary central incisor. Scand J Dent Res. 1973; 81: 335-338.

(Buthina Alhaddad dr., Eger, Deák F. út 43., 3300 e-mail: dr.alhaddad.buthina@gmail.com)

\title{
"All dentists talks while they work. \\ They have inherited this from their professional ancestors, the barbers." \\ (Mark Twain)
}

\author{
(Minden fogorvos beszélget munka közben. \\ Ezt a szokást szakmai elödeiktöl, a borbélyoktól örökölték.)
}

A cikk a Creative Commons Attribution 4.0 International License (https://creativecommons.org/licenses/by/4.0/) feltételei szerint publikált Open Access közlemény, melynek szellemében a cikk bármilyen médiumban szabadon felhasználható, megosztható és újraközölhető, feltéve, hogy az eredeti szerző és a közlés helye, illetve a CC License linkje és az esetlegesen végrehajtott módosítások feltüntetésre kerülnek. (SID_1) 